\title{
DISCOBLOG UNTUK MENINGKATKAN KETERAMPILAN KOLABORASI DAN PRESTASI BELAJAR EKONOMI BISNIS SISWA KELAS X AKL 2 SMK N 1 SUKOHARJO
}

\author{
Purnomo Sidi ${ }^{1}$ \\ ${ }^{1}$ SMK Negeri 1 Sukoharjo, Wonosobo \\ e-mail: purnomosidi1980@gmail.com
}

\begin{abstract}
This study aims to improve students' collaboration skills and learning achievement of Business Economics subject through the implementation of a blog-based Discovery Learning (DiscoBlog). The subject of this Classroom Action Research were 31 students of X AKL 2 class of SMK N 1 Sukoharjo in the even semester of the academic year 2019/2020. The data was collected using observation and tests. The observation was used to find out the students' collaboration skills in applying DiscoBlog through the observation sheet. The test was used to obtain the data about students' learning achievement of Business Economics subject through 25 multiple choice-type questions. The data were analyzed by using descriptive quantitative through a mean score. The results revealed that there was an improvement in students' collaboration skills in applying DiscoBlog. It can be seen by the increase of collaboration skills score from 63,44 in pre-cycle to 83,33 . Besides, there was an improvement in students' learning achievement of Business Economics subject. The mean score showed a rise from 69,10 in pre-cycle with the learning completion $54,84 \%$ to 80,97 with the learning completion $93,55 \%$. Teachers might be able to apply these results to improve the learning quality of Business Economics subject.
\end{abstract}

Keywords: collaboration skills, learning achievement, discovery learning, media blog

Received: 01 Juni 2020

Accepted: 11 Agustus 2020

Published: 28 Desember 2020

\section{PENDAHULUAN}

Perkembangan teknologi informasi telah mengantarkan kehidupan modern memasuki revolusi industri 4.0 yang ditandai dengan berkembangnya berbagai aplikasi berbasis internet yang disebut dengan internet of things. Pengaruh Revolusi industri 4.0 pada dunia pendidikan dikenal dengan pembelajaran abad 21. Pembelajaran abad 21 tidak terlepas dari keterampilan abad 21 yang salah satunya adalah keterampilan belajar dan berinovasi. Seperti yang telah dijelaskan oleh Partnership for 21st Century Learning/P21 (dalam Murti, 2015), keterampilan belajar dan berinovasi meliputi, berpikir kritis dan mengatasi masalah (critical thinking and problem solving), komunikasi dan kolaborasi (communication and collaboration), kreativitas dan inovasi (creativity and innovation). Dengan demikian, siswa diharapkan untuk memiliki keterampilan-keterampilan tersebut sesuai dengan kompetensi bidangnya. 
Salah satu dari keterampilan abad 21 adalah keterampilan kolaborasi (collaboration skills). Kolaborasi juga didefinisikan sebagai kemampuan untuk bekerja secara fleksibel, efektif, dan adil dengan orang lain untuk menyelesaikan sebuah tugas kolektif (National Education Association, 2010). Sato (dalam Purwaaktari, 2015) mengemukakan bahwa kolaboratif adalah hubungan saling belajar yang berangkat dari pertanyaan siswa yang tidak paham, "Bagaimana mengerjakan bagian ini?". Lebih lanjut, diharapkan nantinya siswa yang paham dan yang tidak paham akan mendapatkan manfaat dan terjadi hubungan timbal balik. Metode kolaboratif ini memberi siswa tanggung jawab untuk mempelajari materi dan menjabarkan isinya dalam sebuah kelompok tanpa campur tangan guru (Silberman, 2004). Dalam hal ini, guru hanya sebagai fasilitator dalam proses itu sendiri. Keterampilan kolaborasi siswa ini diperlukan untuk mengembangkan diri dalam belajar sekaligus menyiapkan kompetensi dirinya untuk terjun menjadi tenaga kerja yang kompetitif di era global.

Apriono (2013) menyebutkan bahwa collaborative learning adalah interaksi antara anggota tim, 1) yang dikembangkan dan berbagi suatu untuk mencapai tujuan umum; 2) memberi masukan untuk lebih memahami masalah yang dihadapi; 3) menanyakan, lebih mengerti secara mendalam dan solusi pemecahannya; 4) bereaksi dan bekerja untuk memahami terhadap pertanyaan lain, pengertian yang mendalam dan solusi; 5) masing-masing anggota menguasakan pada anggota lain untuk berbicara dan memberi masukan dan untuk mempertimbangkan kontribusi mereka; 6) dapat dipertanggungjawabkan ke orang yang lain, dan mereka dapat dipertanggungjawabkan kepada dirinya sendiri; serta 7) diantara anggota tim ada saling ketergantungan.

Pada mata pelajaran Ekonomi Bisnis semester genap tahun pelajaran 2019/2020 di kelas X Akuntansi Keuangan dan Lembaga (AKL) 2 SMK Negeri 1 Sukoharjo, siswa belum mampu saling berkontribusi dalam diskusi kelompok. Keterampilan berpikir kritis dan berpikir kreatif siswa juga masih kurang. Selain itu, keterampilan siswa untuk mengakses informasi dari dunia maya masih kurang. Keterampilan kolaborasi sebagian besar siswa juga masih rendah. Keterampilan siswa dalam mengemukakan gagasan atau dalam menjawab pertanyaan masih rendah. Hal ini dikarenakan siswa terbiasa belajar individual dengan media berbasis teks. Berdasarkan hasil pengamatan, siswa kurang menunjukkan keterampilan kolaborasi dengan baik. Rata-rata keterampilan kolaborasi siswa pada observasi awal adalah 63,44. Siswa dengan keterampilan kolaborasi tinggi ada 6 siswa atau 19,35\%. Siswa dengan keterampilan kolaborasi sedang, yaitu sejumlah 13 siswa atau 41,94\%, dan masih ada 12 siswa atau 38,71\% yang memiliki keterampilan kolaborasi rendah.

Keterampilan kolaborasi siswa yang rendah dan metode pembelajaran yang lebih menekankan kerja individu menyebabkan hasil belajar siswa kelas X AKL 2 SMK Negeri 1 Sukoharjo pada semester genap tahun pelajaran 2019/2020 juga rendah. Kriteria Ketuntasan Minimal (KKM) yang ditetapkan sekolah pada mata pelajaran Ekonomi Bisnis adalah 70,00. Pada ulangan harian pertama rata-rata nilai siswa yaitu 69,10. Dari 31 siswa, yang telah mencapai KKM yaitu sejumlah 17 anak atau 54,84\%. Sedangkan siswa yang belum mencapai KKM yaitu sejumlah 14 anak atau $45,16 \%$. 
Prestasi belajar merupakan hasil yang diperoleh seorang siswa setelah melalui proses belajar. Hal ini seperti pendapat Latipah (2010), prestasi belajar mencerminkan kinerja belajar seseorang yang biasanya ditunjukkan dalam bentuk nilai rata-rata yang diperoleh. Jadi, prestasi belajar adalah hasil belajar seorang siswa yang diwujudkan dalam bentuk nilai. Prestasi belajar memiliki hubungan yang sangat dekat dengan hasil belajar. Syah (2010) mengatakan bahwa prestasi belajar adalah "taraf keberhasilan murid dalam mempelajari materi pelajaran di sekolah yang dinyatakan dalam bentuk skor yang diperoleh dari hasil tes mengenai sejumlah materi pelajaran tertentu". Maka dari itu, prestasi belajar identik dengan nilai yang diperoleh seorang siswa pada mata pelajaran tertentu.

Lebih lanjut lagi, Syah (2010) menjelaskan bahwa faktor-faktor yang mempengaruhi prestasi belajar siswa dapat kita bedakan menjadi tiga macam. Pertama, faktor internal merupakan faktor yang berasal dari dalam diri siswa sendiri. Faktor internal terbagi menjadi dua, meliputi faktor fisiologis dan psikologis siswa. Faktor fisiologis seperti penglihatan, pendengaran, struktur tubuh, dan sebagainya, sedangkan faktor psikologis seperti kecerdasan, sikap, bakat, minat, dan motivasi.

Kedua, faktor eksternal merupakan faktor yang berasal dari luar diri siswa/faktor lingkungan disekitar siswa. Faktor eksternal terdiri atas dua macam yaitu faktor lingkungan kolaborasi dan lingkungan non kolaborasi. Lingkungan kolaborasi siswa seperti keluarga, guru dan staf, masyarakat, dan teman, sedangkan faktor lingkungan non kolaborasi seperti adat istiadat, ilmu pengetahuan, teknologi, kesenian, iklim, dan fasilitas belajar. Ketiga, faktor pendekatan belajar (approach to learning) yakni jenis upaya belajar siswa yang meliputi strategi dan model yang digunakan siswa untuk melakukan kegiatan mempelajari materi-materi pelajaran.

Rendahnya keterampilan kolaborasi siswa yang berakibat pada rendahnya prestasi belajar siswa kelas X AKL 2 dimungkinkan karena masih belum diterapkannya strategi, dan model pembelajaran yang berbasis penemuan. Maka dari itu, perlu untuk dilakukan penelitian tindakan kelas menggunakan discovery learning berbasis blog. Discovery learning adalah pembelajaran yang berbasis aktivitas penemuan oleh siswa sendiri. Menurut Setyaningrum, Riani, \& Wardani (2020), model pembelajaran ini efektif diterapkan pada pembelajaran yang membutuhkan kemampuan berpikir tingkat tinggi. Hal ini sesuai dengan karakteristik pembelajaran Ekonomi Bisnis dimana selain membutuhkan keterampilan berkolaborasi juga diperlukan keterampilan berpikir tingkat tinggi. Selain itu, model pembelajaran discovery learning juga terbukti dapat meningkatkan hasil belajar atau prestasi belajar siswa terutama dalam mata pelajaran akuntansi seperti yang dikemukakan oleh Pamungkas (2009), Rachmawati (2016), dan Ginanjar (2020).

Pada penelitian ini, penerapan discovery learning diarahkan untuk melatih siswa mengembangkan keterampilan kolaborasi dan secara bersama-sama menguasai materi pelajaran untuk mencapai prestasi belajar yang lebih baik. Hasil penelitian tentang media berbasis blog yang dirujuk pada penelitian ini juga menunjukkan bahwa penggunaan media dapat meningkatkan prestasi belajar siswa. 
Media blog yang dibuat sesuai materi yang sedang dipelajari, digunakan untuk mendorong siswa berkolaborasi sekaligus membantu untuk memahami materi. Diharapkan dengan berinteraksi pada sintaks discovery learning yang dimulai dari stimulation (stimulasi), problem statement (pernyataan masalah), data collection (pengumpulan data), data processing (pengolahan data), verification (pembuktian), sampai dengan generalization (menarik kesimpulan), maka keterampilan kolaborasi siswa akan meningkat. Keterampilan kolaborasi pada penelitian ini menekankan pada empat aspek dari karakteristik kolaboratif, yakni: 1) saling ketergantungan untuk mencapai tujuan; 2) akuntabilitas dan tanggung jawab personal individu; 3) bekerjasama dalam kelompok; dan 4) komunikasi dalam kelompok. Hal ini dilakukan dengan pertimbangan bahwa karakter inilah yang akan lebih muncul dalam discovery learning yang diterapkan.

Rumusan masalah dalam penelitian ini adalah, 1) Apakah discovery learning berbasis blog (DiscoBlog) dapat meningkatkan keterampilan kolaborasi siswa kelas X AKL 2 SMK N 1 Sukoharjo? 2) Apakah discovery learning berbasis blog (DiscoBlog) dapat meningkatkan prestasi belajar ekonomi bisnis siswa kelas X AKL 2 SMK N 1 Sukoharjo? Tujuan penelitian tindakan kelas ini yaitu, 1) Meningkatkan keterampilan kolaborasi dengan menerapkan DiscoBlog pada siswa kelas X AKL 2 SMK N 1 Sukoharjo semester genap tahun pelajaran 2019/2020. 2) Meningkatkan prestasi belajar ekonomi bisnis dengan menerapkan DiscoBlog pada siswa kelas X AKL 2 SMK N 1 Sukoharjo semester genap tahun pelajaran 2019/2020. Hipotesis tindakan perbaikan melalui penelitian tindakan kelas ini diduga, 1) Penerapan DiscoBlog dapat meningkatkan keterampilan kolaborasi siswa kelas X AKL 2 SMK N 1 Sukoharjo pada semester genap tahun pelajaran 2019/2020, 2) Penerapan DiscoBlog dapat meningkatkan prestasi belajar siswa kelas X AKL 2 SMK N 1 Sukoharjo pada semester genap tahun pelajaran 2019/2020.

\section{METODE PENELITIAN}

Penelitian ini dilakukan di SMK Negeri 1 Sukoharjo, Kecamatan Sukoharjo, Kabupaten Wonosobo. Penelitian ini merupakan Penelitian Tindakan Kelas (PTK) yang dilakukan pada mata pelajaran Ekonomi Bisnis selama 2 siklus. Penelitian dilaksanakan selama 3 bulan yaitu bulan Januari sampai dengan Maret 2020. Subjek penelitian ini adalah siswa kelas X AKL 2 SMK N 1 Sukoharjo yang berjumlah 31 siswa yang terdiri dari 27 siswa perempuan dan 4 siswa laki-laki dengan karakteristik siswa memiliki potensi dan kompetensi yang heterogen. Alasan pemilihan kelas ini karena siswa pada kelas X AKL kurang aktif selama pembalajaran, sehingga hasil belajarnya rendah.

Tes digunakan untuk memperoleh data prestasi belajar mata pelajaran Ekonomi Bisnis. Instrumen yang digunakan terdiri dari 25 soal pilihan ganda, sesuai dengan indikator materi yang dipelajari. Observasi dilakukan untuk mengetahui penerapan DiscoBlog. Instrumen yang digunakan untuk mengamati variabel keterampilan kolaborasi siswa menggunakan lembar pengamatan keterampilan kolaborasi.

Validitas data prestasi belajar meliputi validasi instrumen tes menggunakan validasi empirik dan validasi teoritik yaitu analisis kualitatif dan kuantitatif. Validasi data hasil observasi menggunakan triangulasi sumber dan triangulasi metode. Pada penelitian ini triangulasi sumber menggunakan sumber data yang 
berbeda-beda yaitu data tentang proses melalui siswa dan guru kolaborator. Triangulasi metode untuk mengambil data menggunakan metode yang berbeda yaitu tes, wawancara, dan observasi. Triangulasi pada keterampilan kolaborasi dilakukan dengan observasi oleh peneliti, wawancara yang mendalam, dan observasi guru kolaborator.

Data tes prestasi belajar dianalisis menggunakan Penilaian Acuan Patokan. Penilaian ini mengubah skor yang diperoleh siswa dalam tes menjadi nilai berdasarkan skor maksimum yang menjadi acuan (Purwanto, 2013). Hasil tes prestasi belajar kemudian dianalisis menggunakan analisis statistik deskriptif yaitu kecenderungan nilai tengah (central tendency) dengan mencari nilai rata-rata (mean) untuk membandingkan rata-rata hasil tes dengan indikator kinerja. Sedangkan, data hasil observasi dianalisis dengan menggunakan analisis kuantitatif. Jumlah butir instrumen keterampilan kolaborasi ada 4 dengan skor yang diberikan antara 1-3. Hal ini berarti skor ideal terendah 1 X $4=4$ dan skor ideal tertinggi 3 X $4=12$. Berdasarkan analisis ini, kriteria keterampilan kolaborasi siswa dibuat tiga kategori sebagai berikut.

Tabel 1.

Rentang Penilaian Keterampilan Kolaborasi Siswa

\begin{tabular}{ccc}
\hline Rerata Skor & Rerata Nilai & Interpretasi \\
\hline $10-12$ & $>83,33-100$ & Tinggi \\
$7-9$ & $>58,33-75,00$ & Sedang \\
$4-6$ & $>33,33-55,00$ & Rendah \\
\hline
\end{tabular}

Penelitian ini dilakukan dengan menggunakan metode PTK yang terdiri dari 2 siklus. Prosedur umum PTK, yaitu melalui tahapan planning, acting, observing, dan reflecting. Prosedur pelaksanaan tindakan adalah sebagai berikut. Pada tahap stimulation, siswa diberikan stimulus dengan penayangan gambar-gambar terkait materi. Pada tahap problem statement, peserta didik mendiskusikan dalam kelompok untuk merumuskan pertanyaan berdasarkan hal-hal yang ingin diketahui dari hasil pengamatan lalu siswa bersama kelompok mengerjakan Lembar Kegiatan Peserta Didik (LKPD) yang disediakan guru.

Selanjutnya, pada tahap data collection, siswa mengumpulkan informasi untuk menjawab pertanyaan yang terdapat pada LKPD, serta siswa saling berbagi informasi dan diskusi kelompok untuk mengerjakan LKPD. Pada tahap data processing, siswa secara berkelompok mendiskusikan hasil pengamatan dan menjawab pertanyaan-pertanyaan pada lembar kegiatan berdasarkan data pengamatan dan konsep yang terkait pada buku sumber serta mencatat semua jawaban pada LKPD. Pada tahap verification, siswa mendiskusikan hasil pengolahan data dan memverifikasi hasil pengolahan data dengan teori pada buku sumber. Siswa mengecek hasil pekerjaan teman lain atau mengecek kembali hasil temuan dengan buku sumber dan sumber belajar yang lain. Pada tahap generalization, siswa menyimpulkan kegiatan diskusi secara kelompok dan membuat laporan materi yang didiskusikan dan mempresentasikan hasil temuan untuk dicek bersama oleh kelompok lain dan guru. 


\section{HASIL PENELITIAN DAN PEMBAHASAN Deskripsi Siklus I}

Pelaksanaan tindakan dilakukan sesuai rencana yaitu hari Selasa, 28 Januari 2020 dan Selasa, 4 Februari 2020. Materi yang dipelajari adalah jenis-jenis lembaga keuangan di masyarakat. Data rata-rata nilai keterampilan kolaborasi belajar pada siklus I yang diperoleh menunjukkan kategori sedang yakni 76,88 dengan rincian sebagai berikut:

Tabel 2.

Nilai Keterampilan Kolaborasi pada Siklus I

\begin{tabular}{clcc}
\hline No & \multicolumn{1}{c}{ Indikator } & Nilai & Kategori \\
\hline 1 & Saling ketergantungan & 75,27 & Sedang \\
2 & Akuntabilitas individu & 69,89 & Sedang \\
3 & Bekerja dalam kelompok & 78,49 & Sedang \\
4 & Komunikasi dalam kelompok & 83,87 & Tinggi \\
Rata-rata & 76,88 & Sedang \\
\hline
\end{tabular}

Dari 31 siswa, terdapat 14 siswa atau 45,16\% dengan kategori tinggi, 15 siswa atau 43,89\% dengan kategori sedang, dan 2 siswa atau 6,45\% dengan kategori rendah. Hasil tes pretasi belajar pada siklus I menunjukkan rata-rata nilai 74,45. Nilai tertinggi yaitu 88,00 sedangkan nilai terendah yaitu 52,00 . Siswa yang sudah tuntas belajar ada 26 siswa atau 84\% dan masih terdapat 5 siswa atau 16\% yang nilainya di bawah kriteria ketuntasan minimal (KKM). Persentase ketuntasan belajar siswa pada siklus I sebesar $84 \%$ dalam penelitian ini menunjukkan hasil yang paling tinggi jika dibandingkan persentase ketuntasan belajar siswa dalam penelitian sebelumnya yang dilakukan oleh Pamungkas (2009) sebesar 74,56\%, Rachmawati (2016) sebesar 29\%, dan Ginanjar (2020) sebesar 73,91\%.

Guru kolaborator dan guru peneliti melakukan diskusi refleksi untuk mengetahui ketercapaian pelaksanaan penerapan DiscoBlog pada akhir pertemuan setiap siklus. Diskusi refleksi dilakukan pada hari Selasa, 4 Februari 2020. Kesimpulan dari diskusi refleksi yaitu bahwa keterampilan kolaborasi pada aspek akuntabilitas dan tanggung jawab individu memperoleh nilai paling rendah dengan rerata 69,89. Perencanaan yang lebih intensif diperlukan untuk mendorong kolaborasi. Peneliti berencana menerapkan estafet bamboo talking ketika diskusi kelompok dan proses evaluasi secara individual pada kelompok. Hal ini dimaksudkan agar siswa lebih termotivasi dalam belajar dan muncul tanggung jawab belajar yang lebih besar pada masing-masing anggota kelompok.

\section{Deskripsi Siklus II}

Materi pada siklus II yaitu menganalisis hak dan kewajiban tenaga kerja berdasarkan undang-undang ketenagakerjaan (kompetensi dasar 3.10) dan merumuskan hak dan kewajiban tenaga kerja di lingkungan kerja (kompetensi dasar 4.10). Pelaksanaan tindakan dilakukan sesuai rencana yaitu hari Selasa, 18 Februari 2020 dan hari Selasa, 25 Februari 2020. Sebelum pelajaran dimulai, guru membagi siswa menjadi enam kelompok secara acak, dimana setiap kelompok beranggotakan empat siswa. Materi yang dipelajari adalah tentang penggolongan dan permasalahan tenaga kerja. 
Data keterampilan kolaborasi pada siklus II diambil dengan menggunakan instrumen berupa lembar pengamatan yang terdiri dari empat indikator. Keterampilan kolaborasi belajar pada siklus II tergolong tinggi yakni 83,33. Hasil selengkapnya disajikan dalam tabel distribusi frekuensi sebagai berikut:

Tabel 3.

Nilai Keterampilan Kolaborasi Pada Siklus II

\begin{tabular}{|c|c|c|c|}
\hline No & Indikator & Nilai & Kategori \\
\hline 1 & Saling ketergantungan & 80,65 & Sedang \\
\hline 2 & Akuntabilitas individu & 81,72 & Sedang \\
\hline 3 & Bekerja dalam kelompok & 83,87 & Tinggi \\
\hline 4 & Komunikasi dalam kelompok & 87,10 & Tinggi \\
\hline \multicolumn{2}{|c|}{ Rata-rata } & 83,33 & Tinggi \\
\hline
\end{tabular}

Data hasil observasi menggambarkan bahwa terdapat 22 siswa atau 70,97\% dengan kategori tinggi, 9 siswa atau 29,09\% dengan kategori sedang, dan tidak ada siswa dengan kategori rendah. Hasil tes pretasi belajar pada siklus II menunjukkan rata-rata nilai 80,97. Nilai tertinggi yaitu 100,00 sedangkan nilai terendah 54,00. Siswa yang sudah tuntas belajar ada 29 siswa atau 93,55\% dan masih ada 2 siswa atau $6,45 \%$ yang nilainya di bawah kriteria ketuntasan minimal (KKM).

Diskusi refleksi dilakukan pada hari Jum'at, 13 Maret 2020. Hasil diskusi refleksi menunjukkan bahwa kemampuan guru dalam menyusun perencanaan tindakan sudah baik dan kemampuan guru dalam melaksanakan tindakan juga sudah baik. Secara rinci hasil diskusi refleksi adalah sebagai berikut: 1) terdapat 22 siswa atau 78,57\% yang mempunyai keterampilan kolaborasi tinggi sehingga telah mencapai kriteria keberhasilan karena kriteria keberhasilannya adalah $75 \%$ atau 21 siswa, sehingga telah mencapai kriteria keberhasilan; dan 2) prestasi belajar mata pelajaran Ekonomi Bisnis mencapai nilai rata-rata 80,97 dengan ketuntasan belajar 93,55\% sehingga telah mencapai kriteria keberhasilan karena kriteria keberhasilannya yaitu mencapai nilai rata-rata 70 dengan ketuntasan belajar 75\%. Diskusi refleksi bersama kolaborator ini juga memutuskan bahwa penelitian ini dihentikan pada siklus II karena keterampilan kolaborasi dan prestasi belajar pada mata pelajaran Ekonomi Bisnis telah mencapai kriteria keberhasilan yang ditentukan.

\section{Pembahasan Siklus I}

Penerapan DiscoBlog menyebabkan adanya kenaikan keterampilan kolaborasi dan prestasi belajar pada mata pelajaran Ekonomi Bisnis. Hal ini disebabkan, model DiscoBlog menjadikan siswa aktif bekerjasama, saling mendukung untuk mengerjakan tugas bersama, aktif mencari dan menemukan sendiri materi yang sedang dipelajari, dan berkolaborasi dalam mempresentasikan hasil kerja kelompok. Selain itu, situasi kelas menjadi lebih aktif dan dinamis, penuh aktivitas belajar siswa, dan penuh dengan aktivitas penemuan. Hal ini sesuai dengan yang dikemukakan oleh Sharan (dalam Sumarmi, 2012: 127), bahwa 1) siswa yang berpartisipasi dalam discovery learning cenderung berdiskusi dan menyumbangkan ide tertentu; 2) gaya bicara dan kolaborasi siswa dapat diobservasi; serta 3) siswa dapat belajar kooperatif lebih efektif. Oleh karena itu, discovery learning dapat meningkatkan interaksi kolaborasi mereka. 
Penerapan discovery learning pada materi perpajakan siswa kelas X AKL 2 SMK Negeri 1 Sukoharjo ini menunjukkan adanya peningkatan keterampilan kolaborasi dan prestasi belajar siswa. Hal ini disebabkan adanya desain pembelajaran yang diterapkan sesuai dengan karakteristik mata pelajaran Ekonomi Bisnis. Pada akhir siklus I menunjukkan bahwa hasil siswa yang menunjukkan keterampilan kolaborasi tinggi baru mencapai 45,16\% dan sebagian besar siswa 48,39\% baru mencapai keterampilan kolaborasi sedang sehingga belum mencapai kriteria keberhasilan. Hasil tes prestasi belajar baru mencapai rerata 74,45, sehingga belum mencapai kriteria keberhasilan. Penelitian yang dilakukan oleh Ginanjar (2020) menunjukkan hasil yang serupa untuk nilai ratarata prestasi belajar pada siklus I yaitu 75,21 .

Berdasarkan hasil diskusi refleksi, maka penelitian dilanjutkan ke siklus II dengan menambah kegiatan estafet bamboo talking pada tahap diskusi kelompok dan penilaian proses. Hal ini dimaksudkan agar siswa memiliki tanggung jawab individu yang lebih besar sebagai salah satu keterampilan kolaborasi dan tanggung jawab untuk menguasai materi secara lebih baik.

\section{Pembahasan Siklus II}

Pada siklus II, terdapat 22 siswa atau 70,97\% yang memiliki keterampilan kolaborasi dengan kategori tinggi. Siswa yang memiliki keterampilan kolaborasi sedang berjumlah 9 siswa atau 29,03\% dan tidak ada siswa yang memiliki keterampilan kolaborasi rendah. Hal ini berarti menunjukkan adanya peningkatan kolaborasi dari siklus I dari 14 siswa menjadi 22 siswa. Perbandingan hasil penelitian siklus I dan siklus II setelah dilakukan pengamatan pada saat proses diperoleh data sebagai berikut:

Tabel 4.

\begin{tabular}{|c|c|c|c|}
\hline \multicolumn{4}{|c|}{ Perbandingan Keterampilan Kolaborasi Siklus I dengan Siklus II } \\
\hline No & Keterampilan Kolaborasi & Siklus I & Siklus II \\
\hline 1 & Tinggi & 14 & 22 \\
\hline 2 & Sedang & 15 & 9 \\
\hline 3 & Rendah & - & 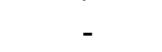 \\
\hline 4 & Rerata & 76,88 & 83,33 \\
\hline
\end{tabular}

Ketuntasan belajar pada siklus II mencapai 93,55\% dengan rerata nilai 80,97. Perbandingan hasil penelitian siklus I dengan siklus II diperoleh data sebagai berikut:

Tabel 5.

Perbandingan Prestasi Belajar Ekonomi Bisnis Siklus I dan Siklus II

\begin{tabular}{cccc}
\hline No & Prestasi Belajar Ekonomi Bisnis & Siklus I & Siklus II \\
\hline 1 & Nilai tertinggi & 88,00 & 92,00 \\
2 & Nilai terendah & 52,00 & 54,00 \\
3 & Nilai rata-rata & 74,45 & 80,97 \\
4 & Ketuntasan Belajar & $83,87 \%$ & $93,55 \%$ \\
\hline
\end{tabular}

Tabel 5 menunjukkan bahwa pada siklus II nilai tertinggi yang diperoleh yaitu 92,00, nilai terendah yaitu 54,00, dan nilai rata-rata yaitu 80,97 dengan ketuntasan belajar sebesar 93,55\%. Sedangkan pada siklus I nilai rata-rata yang diperoleh yaitu 74,45 dengan ketuntasan belajar sebesar 83,87\%. Hal ini 
mengindikasikan bahwa terdapat kenaikan sebesar 9,68\% dari ketuntasan belajar siklus I ke siklus II.

Nilai rata-rata prestasi belajar siswa sebesar 80,97 pada siklus II dalam penelitian ini lebih rendah dari nilai rata-rata prestasi belajar siswa pada siklus II dalam penelitian yang dilakukan oleh Ginanjar (2020) sebesar 87,82. Persentase ketuntasan belajar pada siklus II ini juga paling rendah jika dibandingkan dengan persentase ketuntasan belajar pada siklus II dalam penelitian sebelumnya yang dilakukan oleh Pamungkas (2009), Rachmawati (2016), dan Ginanjar (2020).

Penerapan DiscoBlog dengan variasi estafet bamboo talking mampu meningkatkan keterampilan kolaborasi dan prestasi belajar siswa pada mata pelajaran Ekonomi Bisnis. Hal ini dimungkinkan karena siswa menjadi aktif dalam berkolaborasi. Selain itu, tanggung jawab individu siswa juga meningkat karena ia harus bisa menguasai materi agar bisa menjelaskan pada teman dalam satu kelompok atau ketika menjawab kuis individual.

Hosnan (2014) menyatakan bahwa model discovery learning dapat mengembangkan cara belajar yang aktif dengan menemukan sendiri dan menyelidiki sendiri sehingga hasil yang diperoleh akan tahan lama dalam ingatan. Melalui belajar penemuan, peserta didik juga bisa belajar berpikir analisis dan mencoba memecahkan sendiri masalah yang dihadapi. Langkah-langkah yang ada pada model discovery learning membuat peserta didik harus berkompromi dengan anggota kelompoknya sehingga mampu membuat jawaban. Peserta didik juga dilatih untuk melakukan identifikasi masalah, mengumpulkan data, mengolah data sampai menyimpulkan secara berkolaborasi. Hal tersebut akan membangun semangat mereka menjadi lebih tanggap dan aktif serta cermat dalam menyelesaikan masalah (Balqist, Jalmo, \& Berti, 2019).

Akhir siklus II menunjukkan bahwa hasil keterampilan kolaborasi mencapai rerata 83,33 dan siswa yang telah mencapai kategori tinggi sebesar 70,97\% sehingga telah mencapai kriteria keberhasilan. Hasil tes prestasi belajar yang baru mencapai rerata 80,97 dengan ketuntasan belajar 93,55\% sehingga telah mencapai kriteria keberhasilan. Berdasarkan hasil refleksi, penelitian dihentikan pada siklus II.

\section{Pembahasan Antarsiklus}

Keterampilan kolaborasi siswa pada pengamatan pra siklus yang tergolong kategori tinggi yaitu sebesar 19,35\% atau hanya 6 siswa dari 31 siswa, kategori sedang sebesar 41,94\% atau 13 siswa, dan kategori rendah sebesar 38,71\% atau 12 siswa. Setelah dilakukan penerapan model DiscoBlog, keterampilan kolaborasi siswa mengalami peningkatan. Pada siklus I, siswa dengan keterampilan kolaborasi kategori tinggi sebesar 45,16\% atau 14 siswa, kategori sedang sebesar 48,39\% atau 15 siswa, dan kategori rendah sebesar 6,45\% atau 2 siswa. Pada siklus II, siswa dengan keterampilan kolaborasi kategori tinggi sebesar 70,97\% atau 22 siswa, kategori sedang sebesar 29,03\% atau 9 siswa, dan tidak ada siswa dengan kategori rendah.

Perbandingan nilai rerata keterampilan kolaborasi pada pra siklus, siklus I, dan siklus II adalah sebagai berikut: 
Tabel 6.

Perbandingan Keterampilan Kolaborasi Pra Siklus, Siklus I, dan Siklus II

\begin{tabular}{ccccc}
\hline No & Keterampilan Kolaborasi & Pra Siklus & Siklus I & Siklus II \\
\hline 1 & Tinggi & 6 & 14 & 22 \\
2 & Sedang & 13 & 15 & 9 \\
3 & Kurang & 12 & 2 & 0 \\
4 & Rerata & 63,44 & 76,88 & 83,33 \\
\hline
\end{tabular}

Berdasarkan data pada Tabel 6, terdapat kenaikan rerata keterampilan kolaborasi pada pra siklus 63,44 lalu meningkat menjadi 76,88 pada siklus I dan menjadi 83,33 pada siklus II. Demikian juga untuk data jumlah siswa yang mencapai kategori tinggi mengalami peningkatan dari 6 siswa pada pra siklus lalu meningkat menjadi 14 pada siklus I dan kembali meningkat menjadi 22 orang pada siklus II.

Data peningkatan keterampilan kolaborasi untuk masing-masing indikator disajikan pada grafik berikut:

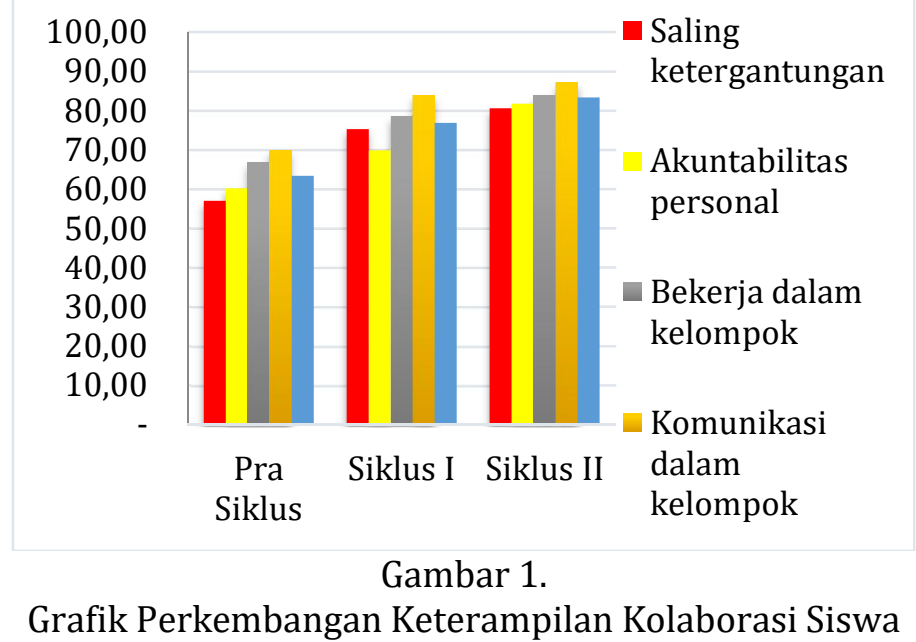

Rerata keterampilan kolaborasi pada siklus I adalah 76,88 dengan siswa yang tergolong kategori tinggi sejumlah 14 siswa atau 45,16\%. Siswa telah aktif berdiskusi dan kerjasama dalam menyelesaikan tugas kelompok. Namun sebagian siswa masih memiliki tanggung jawab individu yang rendah. Pada indikator ini, keterampilan kolaborasi siswa baru mencapai nilai 69,89.

Pada siklus II, penerapan model DiscoBlog divariasikan dengan estafet bamboo talking pada kegiatan diskusi dan kuis kelompok. Hasil pengamatan pada siklus II yaitu terdapat 22 siswa dari 31 siswa atau 70,97\% yang memiliki rata-rata nilai keterampilan kolaborasi 83,33 dengan kategori tinggi, kategori sedang 29,03\% atau 9 siswa, dan tidak ada siswa dengan kategori keterampilan kolaborasi rendah. Indikator saling ketergantungan dan tanggung jawab individu termasuk dalam kategori sedang dengan rerata 80,65 dan 81,72. Indikator kerjasama dan komunikasi dalam kelompok termasuk kategori tinggi dengan rerata 83,87 dan 87,10 . Hal ini dikarenakan keterampilan guru untuk mengorganisasikan kelas semakin meningkat. Penerapan estafet bamboo talking pada kegiatan diskusi dan kuis kelompok telah meningkatkan tanggung jawab belajar individu yang berdampak pada hasil belajar siswa yang lebih baik. 
Prestasi belajar mata pelajaran Ekonomi Bisnis yang diukur melalui tes prestasi menunjukkan hasil rerata nilai 69,10 dengan ketuntasan belajar 54,84\% pada pra siklus. Setelah dilakukan penerapan DiscoBlog, prestasi belajar siswa mengalami peningkatan. Pada siklus I rerata nilainya adalah 74,45 dengan ketuntasan belajar 83,87\%. Sedangkan pada siklus II rerata nilainya adalah 80,97 dengan ketuntasan belajar 93,55\%. Perbandingan hasil tes prestasi belajar pra siklus, siklus I, dan siklus II setelah dilakukan penilaian pada akhir siklus diperoleh data sebagai berikut.

Tabel 7.

Perbandingan Prestasi Belajar Pra Siklus, Siklus I, dan Siklus II

\begin{tabular}{ccccc}
\hline No & Prestasi Belajar & Pra Siklus & Siklus I & Siklus II \\
\hline 1 & Nilai tertinggi & 40,00 & 52,00 & 54,00 \\
2 & Nilai terendah & 84,00 & 88,00 & 92,00 \\
3 & Nilai rata-rata & 69,10 & 74,45 & 80,97 \\
4 & Ketuntasan Belajar & 54,84 & 83,87 & 93,55 \\
\hline
\end{tabular}

Dari data pada Tabel 7, dapat disimpulkan bahwa dengan penerapan DiscoBlog dapat meningkatkan prestasi belajar siswa pada mata pelajaran Ekonomi Bisnis. Perkembangan peningkatan prestasi belajar siswa pada mata pelajaran Ekonomi Bisnis dapat disajikan pada grafik berikut.

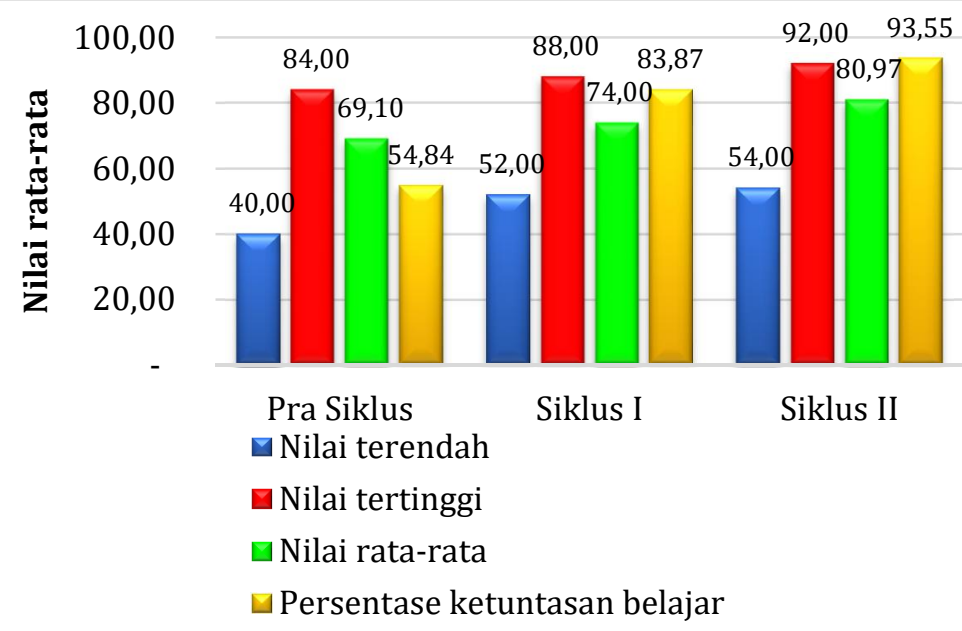

Gambar 2.

Grafik Perkembangan Prestasi Belajar Siswa

Pada siklus II, proses pembelajaran menjadi lebih baik karena guru semakin terampil dalam menerapkan metode dengan variasi estafet bamboo talking pada kegiatan diskusi dan kuis kelompok. Hal ini mendorong peningkatan tanggung jawab individu dalam penguasaan materi pelajaran. Hal ini sesuai pendapat Balqist, Jalmo, \& Berti (2019) yang menyatakan bahwa dengan berkolaborasi akan membuat pekerjaan mereka menjadi lebih efektif dibandingkan dengan individu. Selain itu, soal yang mereka kerjakan menuntut mereka agar mampu berdiskusi dengan peserta didik yang lain (Balqist et al., 2019). Dari uraian tersebut, dapat diperoleh hasil penelitian bahwa penerapan DiscoBlog dapat meningkatkan keterampilan kolaborasi siswa dari 63,44 menjadi 83,33 serta dapat meningkatkan 
prestasi belajar dari rata-rata 69,10 menjadi 80,97 dan ketuntasan belajar dari 54,84 menjadi 93,55.

\section{KESIMPULAN}

Berdasarkan hasil analisis dan pembahasan, maka dapat disimpulkan sebagai berikut. Pertama, penerapan DiscoBlog dapat meningkatkan keterampilan kolaborasi siswa mata pelajaran Ekonomi Bisnis kelas X AKL 2 SMK N 1 Sukoharjo semester genap tahun pelajaran $2019 / 2020$ dari pra siklus 63,44 menjadi 83,33 pada akhir siklus II. Kedua, penerapan DiscoBlog dapat meningkatkan prestasi belajar Ekonomi Bisnis siswa kelas X AKL 2 SMK N 1 Sukoharjo semester genap tahun pelajaran 2019/2020 dari pra siklus 69,10 dengan ketuntasan belajar $54,84 \%$ menjadi 80,97 dengan ketuntasan belajar 93,55\% pada akhir siklus II. Berdasarkan simpulan tersebut, dapat direkomendasikan bahwa peneliti selanjutnya hendaknya menggali data dari berbagai sumber data dalam menerapkan discovery learning. Kedua, pelaksanaan penelitian hendaknya lebih intensif dalam melibatkan kolaborator sebagai observer sehingga dapat melakukan observasi keterampilan kolaborasi pada indikator yang lebih banyak. Ketiga, peneliti selanjutnya sebaiknya menggunakan instrumen penelitian yang lebih valid dan reliabel karena validitas instrumen pada penelitian ini belum memuaskan.

\section{DAFTAR PUSTAKA}

Apriono, D. 2013. Pembelajaran Kolaboratif: Suatu Landasan untuk Membangun Kebersamaan dan Keterampilan Kerjasama. Jurnal Pendidikan Luar Sekolah, 17 (1), 292-304.

Balqist, A., Jalmo, T., \& Berti, Y. 2019. Penggunaan Model Discovery Learning untuk Meningkatkan Keterampilan Kolaborasi dan Berpikir Tingkat Tinggi. Jurnal Bioterdidik: Wahana Ekspresi Ilmiah, 7 (2), 103-111.

Ginanjar, B. W. 2020. Peningkatan Prestasi Belajar Akuntansi Dasar Melalui Penerapan Metode Discovery Learning (DL) Siswa Kelas X Akuntansi di SMK Gajah Mungkur 1 Wuryantoro 2020/2021. Skripsi. Pendidikan Akuntansi, Fakultas Keguruan dan Ilmu Pendidikan, Universitas Muhammadiyah Surakarta.

Hosnan, M. 2014. Pendekatan Saintifik dan Kontekstual dalam Pembelajaran Abad 21. Jakarta: Ghalia Indonesia.

Latipah, E. 2010. Strategi Self Regulated Learning dan Prestasi Belajar: Kajian Meta Analisis. Jurnal Psikologi, 37 (1), 110-129.

Murti, K. E. 2015. Pendidikan Abad 21 dan Aplikasinya dalam Pembelajaran di SMK. Diakses

dari http://pppgkes.com/images/artikel/Pendidikan_Abad_21_dan_Aplikasinya_dalam_ Pembelajaran_di_SMK_-_Kuntari.pdf.

National Education Association. 2010. Preparing 21st century students for a global society: An educator's guide to the "Four Cs." 
Pamungkas, T. O. 2009. Penerapan Discovery Learning Pada Mata Pelajaran Akuntansi untuk Meningkatkan Motivasi dan Prestasi Belajar Siswa Akuntansi Keuangan (Studi Kasus Pada Siswa Kelas X AK SMK Shalahuddin Malang). Skripsi. Pendidikan Akuntansi, Fakultas Ekonomi, Universitas Negeri Malang.

Purwaaktari, E. 2015. Pengaruh Model Collaborative Learning terhadap Kemampuan Pemecahan Masalah Matematika dan Sikap Sosial Siswa Kelas V SD Jarakan Sewon Bantul. Jurnal Penelitian Ilmu Pendidikan, 8 (1), 95-111. https://doi.org/10.21831/jpipfip.v8i1.4932.

Purwanto. 2013. Evaluasi Hasil Belajar. Yogyakarta: Pustaka Pelajar.

Rachmawati, A. 2016. Penerapan Model Discovery Learning Berbasis Lesson Study untuk Meningkatkan Motivasi dan Hasil Belajar Siswa Pada Mata Pelajaran Siklus Akuntansi Perusahaan Jasa di SMK Islam Batu. Skripsi. Pendidikan Akuntansi, Fakultas Ekonomi, Universitas Negeri Malang.

Setyaningrum, W., Riani, A. L., \& Wardani, D. K. 2020. Comparison of Problem Based Learning and Discovery Learning Model. International Journal of Multicultural and $\begin{array}{llll}\text { Multireligious } \quad \text { Understanding, 305-313. } & \text { (3), }\end{array}$ https://doi.org/http://dx.doi.org/10.18415/ijmmu.v7i3.1564.

Silberman, M. L. 2004. Active Learning: 101 Cara Siswa Belajar Aktif. Jakarta: Nusa Media.

Sumarmi. 2012. Model-model Pembelajaran Geografi. Malang: Aditya Media Publising.

Syah, M. 2010. Psikologi Pendidikan. Bandung: PT Remaja Rosdakarya. 